\title{
Sedimentary and environmental characteristics of the Gilan-Mazenderan plain, northern Iran: influence of long- and short-term Caspian water level fluctuations on geomorphology
}

\author{
Nizamettin Kazancı ${ }^{1 *}$, Tirzad Gulbabazadeh ${ }^{2}$, Suzanne A. G. Leroy ${ }^{3}$, Özden Ileri ${ }^{4}$ \\ 1 Gebze Yuksek Teknoloji Enstitüsü, 41400 Gebze, Kocaeli, Turkey, nkazanci@penta.gyte.edu.tr, and Ankara Universitesi Jeoloji \\ Mühendisligi Bolumu, 06100 Besevler, Ankara, Turkey, kazanci@eng.ankara.edu.tr, 2 Payame Noor University, Central Talesh, Iran, \\ tirzadg@yahoo.com, 3 Department of Geography and Earth Sciences, Brunel University, London, UK, Suzanne.Leroy@brunel.ac.uk, 3 \\ Maden ve Tetkik Arama Genel Mudurlugu, 06535 Ankara,Turkey, ozden@mta.gov..tr
}

\begin{abstract}
The south-southwestern Caspian coastal lowland in Iran, or the Gilan-Mazenderan plain, is a relatively narrow but long, composite depositional area of late Quaternary age. The Sefid Rud delta, the Anzali Lake (connected to the Caspian Sea by a meandering outlet $3.5 \mathrm{~km}$ long) and storm-dominated beaches are its prominent sedimentary features. They are controlled by the present water level of the Caspian Sea at $-26.36 \mathrm{~m}$ in 2000. The Late Pleistocene-Holocene deposits of the lowland, which are covered commonly by a modern loess-origin soil, mainly consist of alternations of marine and non-marine sediments. The marine units form coastal terraces at 19-20 m (I), 2-0 m (II) and -6/-8 m (III) corresponing to the Late Khvalinian and Neocaspian transgressions. The deposits of the youngest terrace (terrace III) that represents a prograding beach-ridge complex are a consequence of several medium-term, cyclic water level oscillations in Late Holocene. Just after the initiation of the beach-ridge complex, Lake Anzali formed by damming of rivers and then by progradation of the complex in time forced to form the outlet of the lake. The nearest medium-term cycle lasted c. 65 years between 1930-1995 and the records showed that it included a lot of shortterm (c. 4-5 yrs) and very short-term (week to months) water level oscillations. During the last erratic rise of sea level (1977-1996), the area of Lake Anzali doubled; the delta and the coastal sands including modern beaches were eroded on c. $30-100 \mathrm{~m}$. Overall, a step-like morphology, repetition of marine and non-marine facies and also water level records of the last 75 years indicate that the ancient and recent deposition on the coastal lowland has been controlled by long- medium- and short-term fluctuations of the Caspian Sea level.
\end{abstract}

Key words: Sea level fluctuation, coastal lowland, Lake Anzali, Talesh mountains, northern Iran, Caspian Sea,

\section{Introduction}

Sedimentary sequences in coastal zones and/or the development of depositional coasts are always responses to changes of the sea level. This interaction however often remains interpretative or predictive. On the other hand, in the sequence stratigraphical approach, sea level changes may be reconstructed either from erosional surfaces or from shoreline succession (Reading, 1996). The Caspian Sea is a good example for short- and long-term changes of water level since the Late Pleistocene (Mansimov and Aliyev, 1994). Particularly the documentation on the last century water level changes together with the recent erratic rise of the Caspian Sea level between 1977-1996 clearly provided the opportunity to illustrate the 
sedimentary and hazardous consequences for the whole coastal zone. However published information dealing with the previous and the last sea level changes from the Iranian coast of the Caspian Sea are relatively scarce. The Caspian Sea is a large lake, sensitive to the hydrological balance whose oscillations are common and also periodical (Payan, 1942; Zubakov, 1993; McLaughlin and Anon, 1995; Giralt et al., 2003). The direct relation between the land and the lacustrine system and between the Caspian and the Black Seas has been shown in many studies both offshore and onshore (i.e. Degens and Paluska, 1979; Mamedov, 1997; Kroonenberg et al., 2000; Leroy et al., 2000; Giralt et al., 2003; Marret et al., in press). The Gilan-Mazenderan plain located in the southern Caspian Sea is a very suitable area to understand influences of water-level fluctuations on the development of a coastal wetland (Fig.

The southern coast of the Caspian Sea, typically the section from Anzali to Astara (Fig. 1), consists of ancient and modern sandy beaches. The Sefid Rud delta associated with the lake forms the largest part of the coastal lowland. Many rivers originating from the Talesh Mountains discharge into this lake; so this lake acts as a second order base level of a large drainage basin (Fig. 2). Moreover, when the sea level increases by as much as $2 \mathrm{~m}$, lake water becomes slightly brackish since brackish Caspian Sea water reaches the lake and the lake turns into a large bay with a widening $3.5 \mathrm{~km}$-long outlet. The Anzali wetland and sandy formations near the coast have been described simply as an active lagoon and coastal dunes respectively in some previous literature (i.e. Keudler, 1978; Olah, 1990; Ranjbar, 1998; Talebi, 1998 and DOEI, 1998). However, our new findings do not show the same. The aim of this paper is 1) to present the sedimentary evolution of the region by lithofacies succession, 2) to add more information on the sedimentology and the environment of Lake Anzali and 3) to interpret the geological evolution of the region from the Late Pleistocene to the recent in relation with sea level changes in the short-, medium- and long-term. Correlation of the sediment types and sea level changes over the last 75 years combined with modern evolution of the shoreline is crucial for the understanding of coastal development.

\section{Geological background}

The Iranian Caspian coast is bordered by the Talesh Mountains and/or the NW Alborz belt which is composed of metamorphic, volcanic and sedimentary rocks from the Palaeozoic to the Cainozoic. The Talesh Mountains are sedimentary and an autochthonous part of the Alborz belt; however the latter is mainly metamorphic and volcanic and is a part of AlpineHimalayan system (Stöcklin, 1974, 1977; Sussli, 1976). Together they form a long chain of mountains with heights between 1500 to $4000 \mathrm{~m}$ above the oceanic water level. The mountain belt was formed in the course of collision between the African and the Eurasian continental plates in the Late Cretaceous (Stöcklin, 1977; Şengör et al., 1993; Brunet et al., 2003). The study area is situated in the northern front of the middle part of this belt, known as the southern Caspian depression or coastal lowlands. In geological-geomorphological terms, this depression corresponds to the Gilan-Mazenderan plain of the latest Tertiary-Quaternary (Clark et al., 1975; Berberian \& King, 1981) or to the Mesozoic-Cainozoic subaerial part of South Caspian Basin (Brunet et al., 2003). The basement surface of the South Caspian depression lies at depth of 20-25 km, making it one of the deepest basins in the world. The thickness of the Quaternary deposits is around $2 \mathrm{~km}$. According to a flexural model, subsidence resulting from basinal compression is the main cause for such a fast deposition (Brunet et al., 2003).

The southern Caspian Sea region is seismically active based on many historical and instrumental records of earthquakes (Jackson et al., 2002). A typical fault zone (the Astaran 
Fault zone) bounding the Alborz mountain chain from the north is however covered by Holocene sediments (Novroozi, 1971; Stöcklin, 1977). In general, the region consists of two relatively aseismic blocks surrounded by zones of high seismicity. The southern block, the plateau of central Iran, is moving northward as a semi-rigid block since the Pliocene with a rate of 8-12 mm.yr ${ }^{-1}$ (Axen et al., 2001; Jackson et al., 2002). Along the northern border of Iran, in the Alborz Mountains, the overall direction of motion is toward the NE and the depths of earthquakes here are around 8-15 km. This movement causes compressional deformation throughout the Caspian region; and the South Caspian Basin is now being destroyed by underthrustings on its southwestern and northern margins (Jackson et al., 2002). In spite of this activity, no structural deformation and surface rupture could be detected within the late Quaternary deposits of the study area, except for an uplift of c. 4-6 m. The amount of uplifting was estimated by correlation of the Iranian marine terraces with Cardium edule (a characteristic fossil of the Neocaspian period) with other coastal regions (i.e. Mamedov, 1997).

\section{General geography}

The study site is known as the Gilan-Mazenderan plain bordering the Talesh upland (Fig. 1). Some basic elements such as climate, highland, lowland, Sefid Rud delta, Lake Anzali and modern plant cover are briefly described in this section.

\subsection{Climate}

The southwestern shores of the Caspian Sea including Lake Anzali are usually considered as a humid region and are known as having the Caspian or Hyrcanian climate with mild and wet winters and hot summers. The mean annual precipitation is $1400 \mathrm{~mm}$ with however a range between $1200 \mathrm{~mm}$ and $1900 \mathrm{~mm}$. The Anzali wetland itself receives the maximum precipitation due to local climatic conditions. Precipitation in the heights of the Talesh Mountains is in the form of snow, with the mountain aprons receiving mostly rain. The average and extreme temperatures of summer and winter are $25^{\circ} \mathrm{C}$ and $37{ }^{\circ} \mathrm{C}$ (August) and 9 ${ }^{\circ} \mathrm{C}$ and $-0.8{ }^{\circ} \mathrm{C}$ (January) respectively. Hence it is mostly frost-free at sea level. The relative humidity in the coastal region ranges from 24 to $100 \%$ with an average of $67 \%$ (Gulbabazadeh, 1997). North-easterly winds are dominant and particularly strong in winter and can cause storms that result in large sediment movements in the coastal zone. In the summer, winds from the east-northeast favour the development of hot conditions.

\subsection{Highland: the mountains}

The Talesh Mountains, a part of the Alborz Mountain belts form the drainage areas of the Gilan-Mazenderan plain. There, altitudes are between $3000 \mathrm{~m}$ and $250 \mathrm{~m}$; however elevations of 1500-2000 metres occupy the majority of the highland. More probably due to metamorphic rock composition and their upper vegetation boundary at c. $2400 \mathrm{~m}$, the upper highland has a steep, rugged surface morphology, whereas mid and lower highlands are covered by intense vegetation. Parallel deep valleys occupied by seasonal and perennial rivers are the main morphological features of the northern flanks of these mountains (Fig. 4).

\subsection{Lowland: the Gilan-Mazenderan plain}

The Caspian coastal lowland, or Gilan-Mazenderan coastal plain, that lies between the Talesh Mountains and the Caspian Sea shoreline, is 4 to $50 \mathrm{~km}$ wide and has a crescentic wedge form with the largest part in the Sefid Rud - Anzali region (Figs 1-3). It abounds sharply on mountain aprons (bedrocks) at altitudes of $75-50 \mathrm{~m}$. A topographic escarpment of 5-7 $\mathrm{m}$ above the altitude of $+2-0 \mathrm{~m}$ ( 26 to $28 \mathrm{~m}$ to the Caspian Sea level) is the only apparent 
morphology in the lowland and based on it the plain could be divided locally into upper and lower lowlands. The area is densely populated and abundantly cultivated for tea production and so outcrops are scarce. A dark brown soil cover of at least $3.5 \mathrm{~m}$ has developed. It becomes finer grained and redder in colour downward. It is suggested that the older part of the soil is a loess deposit (Stöcklin, 1971; Clark et al., 1975). Similar, loess-like formations have been also introduced in the Gharatikan area of northeast Iran from Central Asia (Okhravi and Amini, 2001).

The whole Alborz and Talesh mountains including the Anzali region have been mapped previously at scales of 1/ 250000 and 1/ 100000 (Jones, 1971; Davies et al., 1972; Annels et al., 1975; Clark et al., 1975). In these studies the coastal plain was broadly shown as undifferentitated Quaternary; however the presence of the latest Tertiary was detected by fossils in 350 m deep cores (Faridi, 1964). Recently, Gulbabazadeh (1997) has described and mapped some distinct lithofacies in the region (Fig. 3). The deposits of the coastal lowland are until now poorly known and their description and interpretation are amongst the aims of this paper.

\subsection{The Sefid Rud Delta}

The Sefid Rud delta is formed by the longest Iranian river discharging into the Caspian Sea: the $720 \mathrm{~km}$-long Sefid Rud River (Fig. 1). It has a wave-dominated delta with a $110 \mathrm{~km}$ coastline and a $3600 \mathrm{~km}^{2}$ subaerial plain (Gulbabazadeh, 1997). Its drainage basin is over $67,000 \mathrm{~km}^{2}$ and the river Sefid Rud carries 3800 million $\mathrm{m}^{3}$ of water each year to the sea. A large dam however constructed on this river in 1967 in the Manfil area (Fig. 3) prevents significant sediment transportation to the delta (Tolouie et al., 1993) and it resulted in the halt of the progradation and even in the erosion of the delta plain by wave action (Kousari, 1992). In addition, the last rise of sea level caused coastal erosion on up to $100 \mathrm{~m}$ inland.

The sandy sediments of the delta are typically dark gray in colour as they derive from volcanic source rocks in the hinterland (Gulbabazadeh, 1997; DOEI, 1998). They are transported westward by wave and coastal currents and consequently the coastal sand between Anzali and Astara are also dark gray in colour. Alluvial sediments of the river Sefid Rud and lacustrine sediments of Lake Anzali are interfingered in the western end of the delta (Fig. 3).

\subsection{Lake Anzali}

Lake Anzali, also called Bandar-Anzali, Anzali Mordab, Bandar Pahlevi and Enzelli (N $37^{\circ} 26^{\prime} / 37^{\circ} 35^{\prime}-\mathrm{E} 29^{\circ} 15^{\prime} / 49^{\circ} 27^{\prime}$ ) is not only the largest freshwater reservoir of the southern Caspian depression but also it is a very famous wetland as it is one of the first certificated Ramsar sites of the world (1975). Its size and morphology have not been stable for the last century (Payan, 1942; Kimball, 1974), due to climatic and sea level influences. The average water temperature is about $16{ }^{\circ} \mathrm{C}$, with a range from $4.5^{\circ} \mathrm{C}$ in February to 27.5 ${ }^{\circ} \mathrm{C}$ in August. The average depth is around $2.5 \mathrm{~m}$ and its annual areal changes are not regular in places. Lake Anzali receives water and sediments from fifteen rivers originating from the Talesh Mountains (Figs 2, 5 A, B). Its limnological characteristics and sediments will be described below in detail.

\subsection{Modern beaches}

The modern beaches occur typically between Anzali and Astara towns where wave action is predominant (Fig. 3). They have developed on the older sandy coastal deposits. Overall, the sediment is gray sand and its mean grain-size increases toward the west from medium to coarse sand. In the near past mining was common throughout the shoreline, but it became prohibited by law due to environmental hazards (DOEI, 1998). 


\subsection{Regional vegetation and lake phytoplankton}

Lake Anzali is one of the most important and complex habitats of the southern region of the Caspian Sea, according to the introductory information given in its Ramsar site description (1997) and by the DOEI (1998).

\subsubsection{Regional terrestrial vegetation}

The coastal plain around lake Anzali, as well as the northern slopes of Mount Alborz, is part of the Hyrcanian phytogeographical territory (Zohary, 1973). The trees and shrubs belong not only to the Hyrcanian territory but species from the Euro-Siberian, Pontic-MedioEuropean, Euxino-Hyrcanian, Mediterranean and even Sino-Japanese groups are present. The herbaceous species participating to the ground cover have a strong Euro-Siberian affinity (Zohary, 1973).

For the central part of the south Caspian district, the simple altitudinal zonation used by Melchior (Zohary, 1973) is the following: Albizzia and Gleditsia are confined to the lower zone up to $300 \mathrm{~m}$. Parrotia, Pterocarya, Zelkova, Diospyros, Fagus orientalis and Quercus macranthera are dominant trees, mainly from about $1000 \mathrm{~m}$ upwards. The latter reaches the timberline $(2400 \mathrm{~m})$. A montane region is defined from 1500 to $2200 \mathrm{~m}$, which is prolific in perennial herbs and dwarf shrubs, and an alpine region higher up.

Along the Caspian Sea near or on the dune ridges, shrubs (even small trees) of Punica granatum, Mespilus germanica, Gleditsia caspica, Prunus divaricata, Paliurus spina-christi, Morus alba, and Rubus ulmifolius are growing (Emberger and Sabeti, 1962). The Caspian Environment Programme report (DOEI, 1998) mentions on the sea side the presence of Zostera, Potamogeton pectinatus, Ruppia maritima and $R$. spiralis as well as Najas maritima. These macrophytes clearly indicate adaptation to brackish conditions.

Inland, the swampy forest is mainly formed by willows (Salix sp.), poplars (Populus sp.), alders (Alnus sp.), maples (Acer sp.) as well as Pterocarya fraxinifolia, Ulmus campestris, Albizzia julibrissin, Mespilus germanica, Rhamnus grandifolia, Cornus australis and Fraxinus coriariifolia with rare Parrotia persica (Emberger and Sabeti, 1962). The dominant lake vegetation is Phragmites australis, whose extension is favoured by rising sea levels, and Typha. Open waters are colonised by Nelumbo nucifera var. caspica and a very rich growth of other floating and submerged vegetation: Lemna, Potamogeton, Elodea, Myriophyllum, Ceratophyllum, Salvinia, Marsilea, Limnanthemum and Acorus (Emberger and Sabeti, 1962; Ramsar, 1997). In the marshes, one may also find Trapa natans, Juncus spp. and Carex spp. A massive spread of the exotic water-fern Azolla sp. has recently been noted (Ramsar, 1997). The intensity of the vegetation cover and the abundance of each major group in the lake depend mostly on water depth: hence the central sub-basin and the mouth of the outlet are relatively less vegetated (Gulbabazadeh, 1997).

Still in the coastal plain but on drier soils, a forest with tall trees has developed: Quercus castaneifolia, Carpinus betulus, Buxus sempervirens with Zelkova crenata, Ficus, Morus alba, Celtis australis, Ulmus campestris, G. caspica, Albizzia julibrissin, Acer laetum, A. insigne, Tilia rubra, T. caucasica, Diospyros australis and rare Parrotia (Emberger and Sabeti, 1962). This forest has a greater diversity than the swampy forest and is characterised by the absence of Pterocarya fraxinifolia, poplars, and willows (Emberger and Sabeti, 1962). The undercover contains Crataegus (2 sp.), Mespilus germanica, Prunus divaricata and lianas such as ivies (Hedera helix and H. pastuchowii), brambles, wild grapevines and Clematis (DOEI, 1998).

Human impact has modified the vegetation, as the lowland coastal areas are almost entirely cultivated, with patches only of preserved natural habitats. The natural forest has been 
destructed and replaced by tea plantations, citrus trees and rice paddies. The damage done to the local vegetation is especially consequential for the coastal plain and the first hundreds of meters of the northern slopes of the Alborz because of the biodiversity of these zones. Indeed they have been glacial refugia during the Quaternary. Hence the plants surviving there contain the genetic pool that will be used to provide vegetation recolonisation for the next interglacial period (Bennett, 1990). Many plants which are now endemic to the Hyrcanian region, or to the Euxino-Hyrcanian one, were very widespread in Europe until the end of the Early Pleistocene (Leroy and Roiron, 1996): Parrotia persica, Pterocarya, Zelkova crenata and a range of species of limes and maples.

\subsubsection{Caspian Sea and Anzali lake phytoplankton}

The phytoplankton of the Caspian Sea is diverse and contains many endemic species. With respect to salinity the phytoplankton of the South basin is mostly brackish with marine and freshwater elements (Caspian Environment Programme checklist, 2001). Palynological investigations have been undertaken on Last Glacial and Holocene sediments from cores taken in the south basin of the Caspian Sea (Leroy et al., 2000; Marret et al., in press). New organic-walled dinoflagellate cyst genus Caspidinium sp. nov. and new species Caspidinium rugosum sp. nov. and Impagidinium caspienensis sp. nov., together with morphotypes of the species Spiniferites cruciformis have been described (Marret et al., in press). The ecology of these new taxa is hence still poorly known. The other taxa are: Pyxidinopsis psilata, Lingulodinium machaerophorum (a form with bacculae and a form with short spines), cysts of Pentapharsodinium dalei and Brigantedinium spp. Spiniferites belerius has only very rare occurrences. There is not enough information on the phytoplankton in Lake Anzali itself, however intense eutrophication shows the presence of a rich plankton assemblage. The highest population density of plankton occurs in autumn and winter (DOEI, 1998). DOEI (1998) lists some other phyto- and zoo-plankton and benthos.

\section{Data Acquisition}

\subsection{Fieldwork}

A geological-geomorphological survey of the area was conducted in 1994-1996. Satellite images (1985 Landsat TM) and topographic maps at a scale of 1/250 000 were used for mapping the Sefid Rud delta and the lowland boundaries. The limits obtained by this new survey were correlated with previous geological maps produced by Davies et al. (1972) and Clark et al. (1975) to see areal changes of delta and beaches during the recent period of rapid sea level rise. Lithofacies data were mostly collected from channel cuts of the upper river courses following Miall (1984)'s instructions on facies analysis. Several trenches up to $2 \mathrm{~m}$ deep were made on different units by local facilities to check the lithology, as sometimes walls of the river cuts were not clean enough. Eight sections were measured on the coastal sands using quarries of open sand mines. 23 drilling cores provided by the Anzali division of the Department of Environment of Iran were examined for their lithological characteristics (Figs 4 \& 6). In the lake, surface sediments were collected in 18 stations by an Eckman-type grab and four cores $0.5-1 \mathrm{~m}$-long were taken by plastic pipes in the southern marginal zone. The limnological measurements were renewed and enlarged in 1999 using the same localities (Fig. 4, Table 3). To find the transported sediment load from the lake, fifteen samples were collected from the outlet using a bridge at Anzali town. Regular measurements on the rivers for water and sediment discharges and on the coast for sea level changes were provided from the related state offices.

\subsubsection{Instrumental data}


Iranian instrumental records are presented in the Hegira calendar. They have been transformed in the Gregorian calendar.

\subsubsection{Laboratory analyses}

Standard petrographical techniques were applied to sandy sediments for texture and composition. The clay mineralogy of the muddy sediments has been obtained by XRD. A treatment with bromoform was used for the volume of organic matter.

For palynology, five fine -grained surface samples (c. top $20 \mathrm{~cm}$ of sediment, taken in season and year are important) were examined. To achieve this, the samples were treated with the following method: Sodium pyrophosphate, $\mathrm{HCl}, \mathrm{HF}, \mathrm{HCl}$, acetolysis, sieving 120-10 $\mu \mathrm{m}$, slide mounting in glycerol and concentration by the initial addition of Lycopodium tablets. Then the results were plotted as follows: the pollen and spores are presented in the form of a percentage diagram (Fig. 10). The sum for the percentages is made of the terrestrial taxa only (to the left of the column named sum on the diagram). The dinoflagellate and the other microfossils are presented in a concentration diagram (numbers per $\mathrm{ml}$ of wet sediment) (Fig. 11). The plotting software is psimpoll 4.10 (Bennett, 2003). All palynomorphs are well preserved. They present a large taxonomic diversity. The concentration in pollen and spores and other microfossils is high. The one of dinoflagellate is lower.

\subsection{Age model}

The dates used in this study are produced by comparison of the marine terraces in the Anzali area with terraces in the coasts of the Caspian Sea cited in the relevant literature (i.e. Mamedov, 1997; Rychagov, 1997; Kroonenberg et al., 2000). The two morphological terraces at 75-77 $\mathrm{m}$ and 26-28 $\mathrm{m}$ above the Caspian sea surface have been identified earlier by Russian workers and correspond to the Early and Late Khvalinian transgressions (Leontyev and Federov, 1953 in Kobori, 1973). The correlation is based on terrace altitudes, morphostratigraphy, the presence of Caspian fauna (Cardium edule and Didacna sp) and loess deposits. Additionally, subaerial deposits on the marine deposits were ignored when defining the upper topographic limit of a terrace. Mamedov (1997)'s descriptions were adopted for time boundaries of the Late Khvalinian and Neocaspian transgressions. However, it should be noted that the ages and the number of Caspian transgressions and regressions are debated as different dating methods give different results for the same formation (Mamedov, 1997; UnescoIGCP481, 2003). According to our results, the southern Caspian coastal lowland, between the altitudes of $+75 \mathrm{~m}$ and $-26 \mathrm{~m}$, shows two topographical breaks making three terraces at 19-20 $\mathrm{m}$ (I), 2-0 m (II) and -6--8 m (III). They are commonly at higher altitudes by c. 4-6 $\mathrm{m}$ than those of the northern coasts, most probably implying a tectonic uplift (see Jackson et al. 2002 for detail of seismicity in the region). The oldest, terrace $I$ was formed during the Late Khvalinian transgression (17-8 ka), more probably at 17-10 ka BP, while terraces II and III were developed by the Neocaspian transgression and its water level fluctuations around 8-6 ka and 4-1 ka respectively. The subaerial formations (loess and flood plain sediments) formed during regressions and their dates here have been deducted from the regional geological evolution.

\section{Results}

\subsection{Lithofacies of the lowland}

Ignoring the recent deposits of the Sefid Rud delta, Lake Anzali and the modern beaches, one of the best ways to define the lithology of the southern Caspian coastal plain is in five sedimentary facies with the codes A and B (Fig. 3). Facies A1 and A2 (relatively older ones; 
late Pleistocene) are located in the upper lowland, while facies B1-3 (relatively younger ones; Holocene) in the lower lowland. The recent formations, i. e. Lake Anzali and the modern beaches, occur on top of facies B2 and B3 (Figs $2 \& 3$ ). Most of these facies are accessible only by deep river cuts or drillings because of the dense vegetation cover in the region and the lack of sharp relief in the plain.

-Facies A1: This is the oldest, basal facies of the late Quaternary deposits, with very limited outcrops at the southern end of the coastal lowland between $+150 \mathrm{~m}$ and $+50 \mathrm{~m}$ altitudes (Fig. 3 ). The thickness of the facies is uncertain. It is composed of very coarse- grained, poorly sorted, weakly stratified conglomerates with a sandy to gravely matrix. Maximum and mean clast sizes are $150 \mathrm{~cm}$ and $30 \mathrm{~cm}$ respectively. Facies colour varies from gray to brown. It is interpreted as sediments of either colluvium or proximal parts of Quaternary alluvial fans

-Facies A2: This facies occupies places between altitudes of $+50 \mathrm{~m}$ and $0 \mathrm{~m}$, forming the whole upper lowland (Fig. 3), and includes subfacies A2a and A2b. The lower one, subfacies $A 2 a$, comprises a lithology of sand and sandstones with a light gray colour. Apart from river valley walls, three lens-like sediment bodies that form the topographic break mentioned previously are typical exposures of this subfacies. Its thickness is not measurable; however a thickness of $20 \mathrm{~m}$ is suggested by topographic correlation. Individual beds are commonly 2$30 \mathrm{~cm}$ thick and show cross laminations. Bed boundaries are sharp and erosive. The lithology is clay-free, sand and weakly compacted sandstones with abundant marine shell fragments. Grain-size varies from silt to coarse pebble. The main mineralogical constituents are quartz, feldspar, micas and fragments of metamorphic and to a lesser extent volcanic and sedimentary rocks. Sedimentary features of this subfacies indicate that it was deposited in a marine coastal environment.

Subfacies $A 2 b$ is a clay-silt dominated, colourful deposit, which covers subfacies $A 2 a$ unconformably. It has a wedge-like geometry getting thicker toward the bedrocks in the south (3- $30 \mathrm{~m})$. C. $3 \mathrm{~m}$ of the uppermost part represent a modern, brownish soil, while the lower parts are an erodible silty deposits with a red colour. The red, older parts are composed of fine and medium silts. Faint parallel lamination is the only primary sedimentary structure. Overall, the characteristics of this subfacies indicate that a palaeosol-loess complex was sealed by a modern soil. However, previous workers, Barbier (1960) and Davies et al. (1972), have interpreted the entire facies including the modern soil as loess. Loess deposits which originated under an arid climate are well known in Uzbekistan, Tajikistan and the Late Quaternary Russian plain; and the youngest loess-palaeosol complex of Russia can be distinguished within the Late Pleistocene formation (32-26 ka BP) (Velichko, 1990). Okhravi and Amini (2001) have showed the presence and also provenance of the Late Quaternary loess sediments in northeastern Iran. In addition, results obtained from studies of cave, loesslike deposits and lake sediment indicate that there was an arid climate in central and northern Iran until 8 ka BP (Kobori, 1973; Wright et al., 2003) and hence this time interval can be attributed to the formation of subfacies $A 2 b$.

Facies A2 includes terrace $I$. The marine part of it, subfacies A2a, indicates a high water level at 19-20 m. This level is obtained by deducing the thickness of the subfacies A2b (c. 30 $\mathrm{m})$ from the altitude $(50 \mathrm{~m})$ of Facies A2. The formation time is likely to be 17-10 ka BP regarding the possible deposition time of the loess deposits. However, Mamedov (1997) suggested that the Caspian Sea level was probably at $-12 \mathrm{~m}$ in the north during the Late Khvalinian transgression. In addition, the oldest terrace of the southern Caspian Sea was described at $50 \mathrm{~m}$ without considering the thickness of loess deposits and, it was referred to the Early Khvalinian transgression by the Russian geologists Leontyev and Federov (Kobori, 1973). Most probably different interpretations are sourced from local reasons like tectonic uplift, presence and absence of plant and soil covers, erosion. Moreover, the time and duration 
of the transgressions and regressions are still debated (see Mamedov, 1997; Rhychagov, 1997 for details).

-Facies B1: This is the second most extensive marine facies of the Anzali area, accessible only in river cuts. The lower facies boundary could not be observed but it must overly unconformably Facies A2 according to the stratigraphy. It is covered and / or cut by fluvial sediments the Sefid Rud delta in the east (Fig. 3). The facies is also subject to river floods and in some places these recent events prevent soil formation. Facies B1 occurrs at altitudes of between 2-0 $\mathrm{m}$ and $-6{ }_{-}-8 \mathrm{~m}$ and forms terrace II. Its thickness is estimated at $8-10 \mathrm{~m}$ by correlation. The deposit of Facies B1 is a medium to fine-grained, clean sand with marine shells. The texture and mineralogical composition are similar to those of subfacies A2a. We interpret it as the result of the Neocaspian transgression at 8-6 ka BP.

-Facies B2: This is a subaerial facies partly occupied by Lake Anzali (Fig. 3). It overlies unconformably the former marine facies B1. Because of its plain topography, it has recently been subject to floods of rivers and the lake areal change. From this, one can conclude that sedimentation on Facies B2 is still going on and differentiation from older and recent deposits is not unambiguous because of environmental similarities. The sediment of the facies is not directly accessible and it could be observed by trenches and drillings. Its thickness is about 6$8 \mathrm{~m}$ (Fig. 9). The facies is generally composed of alternations of laminated silt and clay; and black clayey layers are typical in the upper layers. The Facies colour is getting redder downward suggesting a fluvial environment. Clays, particularly in the upper layers, include a high volume of organic matter showing marshy environments. This facies was likely formed by alluvial sedimentation (floodplain) at first and later by successive deposition of lacustrine and alluvial sediments, probably after the initiation of coastal sands (facies B3). If the latter is ignored, Facies B2 represents a regressive period of the Caspian Sea, probably between 6-4 ka BP.

-Facies B3: It is observed in the southwestern coasts, typically parallel to shoreline between the towns of Anzali and Astara forming terrace III at $-6 /-8 \mathrm{~m}$. It overlies facies B2 unconformably and is overlain by modern beaches (Figs. 1-3). Facies B3 forms an undulatingtop-ridge morphology c. 5-12 $\mathrm{m}$ high above modern beaches, 0.2 to $2 \mathrm{~km}$ wide, and of several kilometres long between the lake and the sea. Its upper surface is undulating with small smooth hills and depressions; and after heavy rains these depressions turn to shallow ephemeral ponds (Fig. 5 C-F). Some only of these features could be artificial and caused by sand mining, since hill and depressions are right in the present coastal prolongation; undulated surfaces are however common and an original characteristic of an undisturbed beach ridge complex displaying lateral accretion during their formation as seen in modern examples (Reading, 1996; Kroonenberg et al., 2000; Goy et al., 2003).

The surface of the facies deposits is commonly barren, despite some herbaceous and bushy plants. Sediments of this facies have been defined as coastal dunes in some previous literature based on lateral continuity and barren upper surface (i.e. Jones, 1971; Annels et al., 1975; Clark et al., 1975; Davis et al., 1972; DOEI, 1998). Winds can blow fine sands, but according to our observation deflation is not so significant for the destruction of sedimentary features. Human activity is a real threat by mining of these sands for construction material. Particularly between 1960 and 1985, the coastal sands were used in the building of many Iranian dams. Fortunately it stopped after the last rise of sea level. In addition, the poultry industry uses marine shells within the sediment for calcium carbonate.

Open-mine quarries provide good sections for the internal characteristics of the facies. The lithology of the unit mainly is a fine to medium, clean, loose gravely sand associated with 
some silt beds. The sediment colour is usually gray to black. Coarse grains (fine to medium size pebbles) and shells (abundant Cardium edule and Didacna sp.) form distinct layers (Fig. 5F). Low-angle cross-lamination sets and truncation surfaces are common sedimentary features in the sands. The shape of the coarse grains is medium to well rounded. The mineralogical composition of these deposits mainly consists of volcanic shard, rock fragment, feldspar, pumice, quartz and heavy minerals. Quartz is in low percentage (5-25\%) compared to the composition of ordinary coastal deposits. Epidote, hornblende and biotite are common heavy minerals.

Figure 9 shows vertical sections of nineteen 10-20 m long cores taken in the coastal zone. Cores 1-16 are from the eastern end of Facies B3 (Fig. 8). The primary sedimentary structures of the deposits are not preserved in the cores because of the sampling technique; their internal stratigraphy based on lithology remains however clear (Fig. 9). The upper part of the cored succession (c. $12 \mathrm{~m}$ ) generally consists of repetitive layers of silt and sand with marine shell; they are typical sediments of Facies B3. The lower part of the succession is composed of brownish mud and it also includes some organic mud layers. Marine shells are absent. The thickness of this part is around 6-7 m and it belongs clearly to Facies B2. Most probably this non-marine deposit is underlain by another marine facies (B1) but cores are not long enough (Fig. 9). The stratigraphy from the cores shows that the thickness of Facies B3 or the beachridge complex is $10-12 \mathrm{~m}$.

Facies B3, re presenting terrace III, has been deposited during the last high level of the Caspian Sea, most probably at 4-2 ka BP. In spite of limited sediment thickness, the axial continuity of the facies is the result of lateral accretion probably caused by sea level fluctuations during deposition. The beginning of formation of Facies B3 and/or the beachridge complex forced also the initiation of Lake Anzali.

\subsection{Sedimentation in Lake Anzali}

Lake Anzali has a maximum surface of $160 \mathrm{~km}^{2}$ and maximum depth of $5.5 \mathrm{~m}$ (Fig.1). Its area halves down to $70-80 \mathrm{~km}^{2}$ in dry periods. Its average depth is around $2.5 \mathrm{~m}$ and in places depths of 1.5 to $2.5 \mathrm{~m}$ cover large areas (Table 3). The deepest locations are close to the beginning of the outlet (Fig. 8). It is connected and/or discharges to the Caspian Sea with a partly regulated, meandering channel c. $450 \mathrm{~m}$ wide. The water surface of Lake Anzali is only $2 \mathrm{~m}$ above the mean level of Caspian Sea (presently it is at $-26 \mathrm{~m}$ to oceanic level), consequently sea water can temporarily enter into the lake during strong storms or when the Caspian level permanently increases. The latter situation has taken place in the last ten years, particularly between 1991 and 1996.

\subsubsection{Water discharge and sediment transportation}

Lake Anzali receives water from a $3740 \mathrm{~km}^{2}$ drainage basin by fifteen rivers some perennial, some seasonal (Figs $2 \& 3$ ), as well as from spring waters and liquid disposal from many towns and villages. All rivers originate from the lower aprons of the Talesh Mountains and pass the coastal plain with meandering courses 40 to $65 \mathrm{~km}$ long. Therefore their loads are abundantly suspended (Fig. 5 A, B) and only two of the rivers, Behember and Pirbazar, transport gravely bed load (Gulbabazadeh, 1997). Rivers Halkai, Masule-Rud, Kolser, Pesihan and Sheijan have a large debit but carry almost only suspended sediment (Tables 1 and 2). According to long-term measurements by the Anzali Office of Water Works of Iran, rivers Pesihan, Pirbazar and Shah Hazer provide up to $57 \%$ of the sediment annually transported into Lake Anzali (Table 2). The water regime of these rivers is relatively irregular and dependent on the thickness of the snow cover on the Talesh Mountain; large discharges are however generally measured at the end of spring or in early summer (Table 1). Sediment transported to the lake by perennial rivers is c. 500,000 ton. $\mathrm{yr}^{-1}$ (Table 2). This is a small load 
volume compared to the size of the drainage basin and the climatic humidity of the region. The sediment concentration of rivers is below $1 \mathrm{~g} / \mathrm{l}$ even during periods of strong discharge and it is not parallel to river debits (Table 1). It may be the result of intense vegetation cover in the region. This situation is quite different from areas suffering intense erosion where rivers have a large load, such as large parts of Anatolia (Kazanci et al., subm.). Taking into consideration the presence of many ephemeral streams, it is estimated that the annual load transported to lake Anzali is around 700,000 tons.

The outlet of Lake Anzali also is a sediment transport channel from the lake to the Caspian Sea. According to our observations at the Gazian Bridge that crossed the outlet just at the Anzali town, the average sediment concentration was $0.14 \mathrm{~g} / \mathrm{l}$ in 1995-2000. From this, it can be assumed that nearly half of the sediment derived from the drainage area is caught in Lake Anzali. The comparison of heavy metal concentrations between lacustrine and coastal sediments further proves the entrapment of sediments in this lake; the pollutants are quite abundant in lacustrine water and sediments but significantly lower in marine sediments deposited on the shores of the Caspian Sea (Ranjbar, 1998; De Mora and Sheikholeslami, 2002).

\subsubsection{Chemical characteristics of lake water}

The water quality of Lake Anzali has deteriorated because of wastewater and pollutants such as pesticides and other fertilizers used in farming (Ranjbar, 1998; Talebi, 1998). It however changes seasonally (Tables $3 \& 4$ ). The average water temperature is about $16{ }^{\circ} \mathrm{C}$, with a range from $4.5^{\circ} \mathrm{C}$ in February to $27.5{ }^{\circ} \mathrm{C}$ in August. The concentration of dissolved oxygen in the water depends on the water depth, the discharge into the lake and the amount and type of vegetation cover. The dissolved oxygen ranges from 1 to $13 \mathrm{mg} / \mathrm{l}$, and chemical oxygen demand (COD) ranges from 13.8 to 176.4 units. The $\mathrm{pH}$ varies between 7.82 and 9.16, although it is lower in river waters: $7.2-8.3$. The salinity of Lake Anzali displays variations based not only on seasons but also on water depth and distance from the Caspian Sea shore (Tables $3 \& 4$ ). Its average is $1.5-1.75 \%$. In winters and springs, when water discharge is high, salinity is lower than in the other seasons. In addition, a slight salinity difference is recorded between water surface and bottom in each season. This is especially apparent near the outlet (Stations 3 to 5; Table 3). Based on long-term salinity measurements, the division of Lake Anzali into sub-basins is traditional in local studies (DOEI, 1998). They are A- Siahkeshim, salinity $=0.23 \%$ o, B- Sheijan, salinity $=0.43 \%$ o, C- West and central basins, salinity $=0.7-2.5 \%$ o, D- Channels of the outlet, salinity $=1.57-2.1 \%$ o.

Water chemistry shows that the salinity is principally based on concentrations of chlorine, sulphate and natrium. there is no strong water circulation in the lake (Table 3) (Table 4) as salinity and ion concentrations reamian clearly different in different places. Moreover, during strong storms, Caspian Sea water affects the water in the outlet by mixing or causing a gradient of salinity. In any case, when taking into consideration the salinity of the Caspian Sea of $12.5-13.5 \%$, the water of Lake Anzali, excluding its central sub-basin and outlet, is typically limnetic or fresh $(<0.5 \% 0$; Venice System, 1959). This freshwater character of Lake Anzali remains the same when the Caspian Sea level increased or decreased except during inundation of the lake by sea water (i.e. Keudler, 1978; Olah, 1990). 


\subsubsection{Lake sediments}

The modern bottom sediment of Lake Anzali is generally a combination of organic and inorganic mud with a strong odour. The colour of the sediment is black, more rarely dark gray in the central basin. The analyses of samples from 18 stations showed that the volume of organic matter is between 12 and $18 \%$. Inorganic material consists of $0-5 \%$ of sand, $5-55$ $\%$ of silt and $40-90 \%$ of clay. Grain size decreases sharply from the lake margin to the centre. However the deposits of some islands in the lake are coarse-grained; and even pebblesize clasts can be found. These lacustrine islands are formed by rivers as mouth bars at the lake margins when the water level dropped; consequently it is a mixture of different sizes and different volumes of sediments.

Quartz, feldspar, calcite, volcanic shards, pyroxene (egirineogite, pigeonite) and apatite are frequent minerals found in the coarsefraction. Based on XRD analysis, the main clay minerals of the Lake Anzali mud are illite, chlorite, smectite, interstratified clays and vermiculite. Such mineral assemblage covering a large paragenesis indicates that sediments of Lake Anzali are transported from both the lowland and the Talesh Mountains.

The thickness of modern lacustrine mud is estimated at up to $5 \mathrm{~m}$ according to consideration of some local characteristics such as morphology, thickness of old lacustrine sediments (facies B2), depth of lake water, height of coastal sands of Facies B3. This is a small thickness and indicates a low rate of sedimentation compared to volume of annual sediment load (around 700,000 tons) and also to other freshwater lakes (Kazanc1 et al. subm). The reasons, either the lack of accommodation space or the fast discharge via the outlet, remains unclear.

\subsubsection{Palynological remains}

The terrestrial diagram

The AP/NAP ratio is high in all samples (always > $76 \%$ ) (Fig. 10). The tree pollen is largely dominated by Alnus. Other important arboreal pollen taxa percentages are Carpinus betulus $\mathrm{t}$. and Fagus. The non-arboreal pollen percentages are dominated by Gramineae, Amaranthaceae-Chenopodiaceae and Artemisia.

All broad altitudinal vegetation belts are represented in the Anzali spectra. The various components of the terrestrial vegetation around lake Anzali are recorded in the surface sediment: a) the lowland and coastal forest by Carpinus betulus, deciduous Quercus, UlmusZelkova, Pterocarya and Parrotia persica pollen, with Pteridium aquilinum spores from ferns in forest clearings, b) the riparian trees: Alnus and c)the lianas: Vitis, Hedera. The altitudinal forest is represented mainly by Fagus. Agriculture is reflected mostly by Cerealia and indirectly by Urticaceae (ruderals), Plantago lanceolata (pastures or meadows) and Rumex. A group very well represented in the spectra is the one of the dry elements (steppe and saline soils): Ephedra (2 taxa), Amaranthaceae-Chenopodiaceae, Artemisia, Haplophyllum. These plants probably grow along the coast or at altitudes above the treeline.

The aquatic vegetation is recorded by pollen from emergent plants Typha ( 2 taxa), rooted plants Myriophyllum, Potamogeton and Ceratophyllum. The massulae of a floating fern have been found: they belong either to Salvinia, frequent around the Caspian Sea or to Azolla, a recent massive invader (Ramsar 1997). Most of the Gramineae (likely Phragmites australis, which has been observed to spread rapidly recently, Ramsar 1997) and Cyperaceae belong to the vegetation belt around the lake.

\section{The dinoflagellate diagram}

The dinoflagellate assemblage of the Anzali lake (Fig. 11) corresponds to that of the bottom sediment of the deep south basin of the Caspian Sea. Only Pyxidonopsis psilata is 
absent from the lake. The concentration in the lake sediment (largely dominated by Impagidinium caspienensis) is c. 7 times higher than that of the deep sea sediment.

The concentration in dinoflagellates decreases away from sample 4 to the west and to the east, whereas the one of other microfossils increases. This illustrates well a salinity gradient in the lake with the highest salinity near the channel through which Caspian Sea waters penetrate in the lake.

\section{The other palynomorph diagram}

The palynomorphs listed under "others" are for most of them derived from plants, animals, cyanobacteria and fungi growing/living in/near freshwater (Fig. 11). Some of the forms are only poorly known, such as the three forms attributed to Prasinophytes (5b, 5c and $5 d$ ). These are also present in the Caspian Sea samples (Marret et al., in press). The two dominant forms are Tetraedron, a green alga, and Anabaena, a cyanobacteria.

The abundance of green algae and cyanobacteria (along with aquatic macrophytes) is most likely linked to a tendency to eutrophication of the waters. Ramsar site description (1997) indicates indeed a major eutrophication due to pollution by pesticides and fertilizers.

\section{General comments}

In general, sample 4 spectrum from the deepest part of the lake is more influenced by longdistance transport by air and by river, as indicated by higher percentages of Fagus (mountain) and dry elements. It is the same sample that has the highest concentration in dinoflagellates and the lowest one in other microfossils, indicating a clear "marine" influence also.

The good preservation of a very diverse palynoflora indicates that for the future this technique can be used in lake Anzali to reconstruct both terrestrial and aquatic environments and their evolution through times. Climatic, tectonic and human impact can potentially be studied in this locality.

The diversity and the history of the flora is quite unique: a relict forest, many endemic species (from trees to dinoflagellates) and new species remaining to be discovered, all concur to underline the importance of the area for conservation.

\section{3. Sea level fluctuations and records at the Anzali town (city if it is large)}

After examining the geological record with long-term fluctuations, the instrumental record analysis provides a perspective on the medium-, short- and very short-term fluctuations of the sea level. Water level fluctuations of the Caspian Sea have been observed since 1829, as they are the main threat for the coastal zones. These medium-term changes are even considered by some to be one of the most important environmental hazards of the world in the last decade because of its amplitude : a sea level rise of about $2.5 \mathrm{~m}$ in less than 20 years (Mansimov and Aliyev, 1994). In the coastal zone, the marine flood has ruined or damaged constructions and other artificial structures, roads and farmlands. It also resulted in changes in water regime, behaviour of river mouth, composition of ground water, biological communities in the littoral zone, sediment transportation and pollution of the coastal zone by heavy metals, petroleum and other organic substances (Mansimov and Aliyev, 1994; DOEI, 1998). The international scientific interest focused on the understanding of the event and on the forecasting of future trends, but until now a nagreement on the reasons of the fluctuations could however not be obtained yet. The most common suggestion is atmospheric / climatic conditions, particularly water discharges from rivers 1000 km north (Sedledski and Baikov, 1997; Rychagov, 1997; Escudié et al., 1998). Relatively little scientific contribution to the debate came from the south Caspian Sea region in spite of the existence of a complete, sea- level record nearly one century long made by Iranian observatories. 
The last rapid rise of the Caspian Sea (1977-1996) had significant effects on the coastal Iranian lowland including the Sefid Rud delta and Lake Anzali. The delta and sandy beaches regraded by c. 30-100 $\mathrm{m}$ during this period. The lowlands and Lake Anzali were inundated; the lake surface doubled from 80 to $160 \mathrm{~km}^{2}$ (Fig. 4). In fact, the old marine deposits show that long-term fluctuations of the Caspian Sea have been frequent since the Late Pleistocene. They are the Late Khazarian (114-75 ka), Early Khvalynian (32-24 ka), Late Khvalynian (16$8 \mathrm{ka}$ ) and Neocaspian (8 ka to Recent) transgressions. Terraces (I to III) of the Anzali region (see above) have been produced by the last two transgressions. The Neocaspian transgression is debated as its sedimentary results (= terraces) are not as high as others and so Mamedov (1997) describes it as a regression after the Late Khvalynian [homogenise spelling] transgression. Despite this, the Anzali terraces of Neocaspian age are fairly consistent and they reflect significant high water levels. Terrace III of the Late Holocene in this study site is a prograding beach-ridge complex (see above). Coastal progradation usually results from water level oscillations (Kroonenberg et al., 2002). Cyclic fluctuations of the Caspian Sea in the last 3500 years are however very clear from terrace studies (Zubakov, 1993; Mamedov, 1997; Rychagov, 1997). The cycle has a 450-500 yr-periodicity with a sea level rise of c. 20 $\mathrm{m}$ in the Late Holocene (Rychagov, 1997). However the last cycle has lasted only 65 yrs and the rise has been $3 \mathrm{~m}$ maximum as shown by record in northern Iran and the Dagestan coasts (Fig. 6) (Kroonenberg et al., 2000).

Figure 6 shows a full sea- level record of the last 75 years based on daily measurements at Anzali town. It is noteworthy that there is a one-year shift in maximual and minimal levels between Iranian records and data of relevant literature and this after transformation of the Iranian hegire?? calendar into the Gregorian one (i.e. Mansimov and Aliyev, 1994; Sedledski and Baikov, 1997; Cazenave et al., 1998; Kroonenberg et al., 2000). Additionally, values of water level of the Caspian Sea also show an increase from the south to the north. Its reason is not understood well yet: the strongest suggestion being water coming from the Volga (Cazenave et al., 1998). The records at Anzali (Fig. 6) show that the highest sea level was in 1930 at $-25.25 \mathrm{~m}$ and then dropped to $-27.00 \mathrm{~m}$ in 1945 . The decrease gradually continued to $-28.20 \mathrm{~m}$ in the following 30 years. Fluctuations with a four-year periodicity (= short-term changes) occurred in 1945-49, 1950-54, 1960-64, 1965 -69. Later it increased erratically up to $2.5 \mathrm{~m}$ from $-28.44 \mathrm{~m}$ of 1977 to $-26.29 \mathrm{~m}$ of 1996 . In 2000 , it was at $-26.36 \mathrm{~m}$. It is estimated that sea water level will decrease again to $-28 \mathrm{~m}$ in the next years (reference). The legal limit of the safe zone has been however established at $-22 \mathrm{~m}$ in the Iranian coast, considering water level may increase by $13 \mathrm{~cm}$ annually within the next 30 year (DOEI, 1998). The absence of tide-related water level changes in the Caspian Sea is a fortune for the management of the coastal zone. A consensus about the Caspian Sea is that it is sensitive to hydrological changes in its drainage area (Payan, 1942?; Zubakov, 1993; Mescherskaya and Aleksandranova, 1993; McLaughlin and Anon, 1995). Parallel to the Caspian Sea, a similar rise of water levels in Lake Ormiyah (or Urmia, Iran) and lakes Van and Erçek (Turkey) [Nizamettin: are they all in the drainage basin of the Caspian sea?] between 1988-1995 supports this interpretation (Anonim, 1996).

Very short-term or sharp oscillations of the Caspian Sea level are common. They are formed weekly or daily either by winds coming from the NE or by seiches according to records by observatories at Anzali (Fig. 7). The sea level has been recorded there three times every day at hours $08.00,12.00$ and 18.00 [move to methods?]. During the storms, the range of water level changes can reach up to $1.5-2 \mathrm{~m}$; it remains however around $45-50 \mathrm{~cm}$ and $5-15 \mathrm{~cm}$ in moderate windy days and calm days respectively. In a one-year period (1999-2000), the sea level reached a maximum of $-26.09 \mathrm{~m}$ and minimum of $-26.74 \mathrm{~m}$ hence a difference of 0.65 
m (Fig. 7). Seiches can also create rapid (several hours) water level changes of $80-100 \mathrm{~cm}$. The present records show that these sharp oscillations are generally much more apparent in the afternoons and in winter month (Fig. 7). The negative parabolic curve character of the annual changes $\left(y=-4 E-06 X^{2}-4924,8\right)$, opposite to that of changes in a century $(y=0,00616$ $\left.X^{2}-6,365 X+6234,2\right)$ is a good reflection of the very short-term, sharp oscillations in the records (Figs $6 \& 7$ ).

\section{Discussion and conclusions}

The results summarized in the previous sections show well the oscillatory nature of the water level of the Caspian Sea over the last millennia. They can be categorized into four groups based on duration; a- long-term changes (thousands years), b- medium-term changes (ten to hundreds years), c- short-term changes (one to ten years), d- very short-term or sharp changes (hour to several months). The Caspian Sea system is truly unique as the number and the amplitude of these fluctuations find very little equivalent elsewhere in the world

Sedimentary imprints of all these changes are found within the sediments of the GilanMazenderan plain in northern Iran. Three marine terraces at 19-20 m, 2-0 m and -6_-8 m and related deposits (facies A2a, B1 and B3) indicate long-term high water levels or transgressions of the sea. The non-marine, regressive facies (facies A1, A2b, B2) are relatively thin $(5-30 \mathrm{~m})$ and one of them (facies A2b; a loess-soil complex) illustrates a dry, wind- dominated climate at 10-8 ka BP. The colonisation of the region byHyrcanian plant cover followed that dry period. The medium-term water level changes became effective on the formations of terrace III (Facies B3 or a beach-ridge complex) while the short-term changes act on the modern shores.

\subsection{Evolution of the lowland}

[from here: The southern coastal lowland of the Caspian Sea is essentially a continental part of the Southern Caspian Depression. The latter is bordered to the south by the Albrouse (please keep the same spelling all through) Mountain chain up to $3500 \mathrm{~m}$ high (Talesh mountains in Anzali area) and to the north by a submarine sill that separates it from the middle basin. The present average and maximum water depths of this depression are about $190 \mathrm{~m}$ and $1025 \mathrm{~m}$ respectively (Marret et al., in press). So, it has a c. $4500 \mathrm{~m}$ relief between its bottom and top, probably since its formation. Due to the presence of oilfield, the depression has been well studied and so it is known that subsidence has been very effective in the region (Brunet et al., 2003); but there are hardly any signs of active tectonics creating structural deformation or surface rupture within late Quaternary sediments. The present host rock and / or geological substratum of the southern Caspian lowland is Neogene deposits of the eastern Paratethys, mostly Pliocene sediments from the Caspian basin (Davies et al., 1972; Clark et al., 1975), although they are known only from wells because of a thick late Quaternary sediment cover. In addition, the boundary between the series of Neogene and Quaternary and its elevation limits are unclear (probably due to the shortage of detailed studies). To here, move to 3.2?]

Stöcklin et al. (1969) found the highest depositional terrace of the region at $260 \mathrm{~m}$ in the valley of Kale Rudkhan in the northern Alborzs. They interpreted that this terrace belonged to the Great Balkhany(spelling ?) Lake (is this a meltwater lake??) covering the Aral and Caspian seas during Pleistocene time. The highest marine deposits in the study are at $+20 \mathrm{~m}$ (facies A2a) and they probably represent the early stage of the late Khvalinian[homogenise 
spelling] transgression (17-8 ka BP). The other facies have formed on it as a descending order of steps. This morphostratigraphic pattern suggests that deposition took place during progradation of the coast after the fast transgressions of the late Khvalinian? and the Neocaspian. The latter (8-0 ka BP) has led to the formation of a beach-ridge complex (coastal sands), the Sefid Rud delta and the Anzali Lake.

\subsection{Coastal sands}

The most significant sedimentary feature of the region is the coastal sands (facies B3) described as coastal dunes traditionally in the local literature (see above). Discussion and clarification of the origin of this formation is important not only for the evolution of Lake Anzali but also for the Holocene geographical setting of the region. Internal features of the deposits (i.e. low-angle cross-sets dipping mostly toward the sea, gravel beds, unsorted or mixed grains (silt and sand) and coquina layers with some unbroken Cardium and Didacna shells) show that they are in situ (Figs 5E, 9). Their uppermost part is however artificially disturbed. They were most probably deposited as a beach ridge complex. Such formations are common in high-energy coasts, particularly in the case of short- and long-term water level changes (Reading, 1996; Goy et al., 2003). On the other hand, coastal dunes, although a kind of coastal sand accumulation, are formed over many years when windblown sand is trapped by shore plants or other stationary objects (Nordstorm et al., 1991). Plants, especially grasses, anchor the dunes with their roots, holding them temporarily in place, while their leaves trap sand promoting dune expansion. Without vegetation, wind and waves regularly change their form and location; and so coastal dunes are not permanent structures (Reineck and Singh, 1980). Sand is usually transported by saltation in which very seldom grains get more than one foot off the ground and so they are typically sorted (Knight et al., 2002). All these grain characteristics and type of deposits do not fit the coastal sands studied here, particularly the presence of fine silt layers (Fig. 9). In addition, there is not any sign of recent or past movement of the sandy deposits toward the land. Probably, the humid climate and hence wet upper surface of the formation have not permitted the windblown process. Therefore the beach ridge complex of late Holocene has been inherited today as a coastal sand field.

\subsection{Evolution of Lake Anzali}

Lake Anzali, draining water from an area of $3740 \mathrm{~km}^{2}$, is the largest fresh water body of northern Iran. The geographic situation of the lake, with an outlet to the Caspian Sea, may suggest a lagoon, i. e. a depositional place that has been gained from the sea (Reineck and Singh, 1980). It is however a dammed lake in origin. Lithofacies B2 is a lacustrine unit around Lake Anzali and the topographic elevation of its base boundary with lithofacies B1 is higher than that of the coastal barrier. Even only this relation can prove the lake has an evolutional development based on coastal dynamics. The water level of the Caspian Sea and coastal sands clearly are primary factors for its developments. The sands transported from the Sefid Rud delta probably accelerated the formation of the coastal sand ridges. Our interpretation is that coastal ridges and/or dunes formed at first and so they prevented alluvial discharge into the sea individually. Streams coming from the Talesh Mountains had to meet or join each other at a place where the present lake developed owing to the presence of sand ridges (Fig. 3). Probably the new large river was going to the sea following the same itinerary that the present outlet and it would have built a delta. Progradation of the coastal zone by the development of beach ridges was so fast (because of sediment availability from the Sefid Rud delta) that the coastal sands (terrace III, Facies B3) formed a dammed lake in a limited time. (Medium?)Short-term sea-level changes were likely effective on that development when it is compared with modern dynamics. 
Lake Anzali surface and its outlet are at c. $-24 \mathrm{~m}$ and consequently have been affected by the present sea level (c. $-26 \mathrm{~m}$ ) particularly for the last fifteen years (Figs. 4, 6). Now it has a surface area of $160 \mathrm{~km}^{2}$. It was only $80 \mathrm{~km}^{2}$ in summers of $1971-73$ but $218 \mathrm{~km}^{2}$ in winters of these years (Kimball, 1974). In winter of 1940 and 1935 the lake area was $200 \mathrm{~km}^{2}$ and 259 $\mathrm{km}^{2}$ respectively (Payan 1942; DOEI 1998). During these years, the water level of the Caspian Sea was as high as at present (Fig. 7).

The water depth of Lake Anzali presents significant seasonal variations in different places (Table 5). The difference (maximum $175 \mathrm{~cm}$ ) is relatively high in the eastern and central sub-basins. In addition, maximum water depths are reached in different seasons. For example, the greatest water depth of Station 9 is $220 \mathrm{~cm}$ in summer but it is $240 \mathrm{~cm}$ for Station 6 in winter (Table 3). According to our interpretation, it is not a real change of the water level in a year. However, combined with seasonal fluctuations, the causes are changing bottom topography both by rapid sediment accumulation and by bottom erosion particularly during stormy periods. It is thought that water level of the Caspian Sea affects the erosion or sedimentation in the lake. The last, but not least, seasonal correlation of water levels of Lake Anzali and the sea show that fluctuations are not in good agreement (Table 3, Fig. 7). This is likely due to sharp and short-term water level oscillations in the Caspian Sea; and these types of water level changes have a decisive impact on the coastal development.

\section{Acknowledgements}

The manuscript benefited largely from unpublished data in the $\mathrm{PhD}$ thesis of T. Gulbabazadeh prepared by the support of the Research Fund of Ankara University under supervision of N. Kazanc1. The authors are grateful to the General Directorate of Iranian Seaport and Shipment for providing water level records of the Caspian Sea together with technical facilities during the fieldwork, to the Directorate of Environment of Iran for past chemical records of Lake Anzali, to Ediz Kurman of Ankara University and to Ali Aydemir of Gebze Institute of Technology for drawings the figures.

\section{References}

Annels, R.N., Arthurton, R.S., Bazley, R.A., Davies, R.G., 1975. Explanatory text of the Qazwin and Rasht quadrangles. Geological Survey of Iran, E3 and E4 maps, 94 pp, Tehran.

Anonim, 1996, Van Gölü Simpozyumu (12-15 Mart, 1996) Kitabı. Van Valiligi, Van, 182 pp.

Axen, G.J, Lam, P.S., Grove, M. and Stockli, D.F., 2001. Exunation of the west-central Alborz mountains, Iran; Caspian subsidence and collision-related tectonics. Geology 29: 559-562.

Barbier, R., 1960. Decouverte de loess et d'une anciennevalle ramblayee dans le cour inferieur du Sefid Rud (versant nord de l'Elbrouz, Iran). Comptes Rendus Acad. Sci. $250: 1097-1098$

Berberian, M., King, G.C.P., 1981, Towards a palaeogeography and tectonic evolution of Iran. Can. J. Earth Sci., 18, 210-265.

Bennett, K. D. (1990). Milankovitch cycles and their effects on species in ecological and evolutionary time. Paleobiology 16, 1, 11-21.

Bennett K., 2003 - http://www.kv.geo.uu.se/psimpoll.html 
Brunet, M.F., Korotaev, M.V., Ershov, A.V., Nikishin, A.M., 2003. The South Caspian basin: a review of its evolution from subsidence modelling. Sediment. Geol., 156, 119-148.

Caspian Environment Programme cheklist 2001 Caspian Environment Programme http://www.grida.no/caspian/additional_info/habitat.pdf (FORMAT?)

CEP (Caspian Environment Programme) 1998. Regional action plan for protection of Caspian habitats. CEP, RER/98/g32/A/1G/31, www.grida.no/caspian/additional_info/habitat.pdf

Cazenave, A., Dominih, K., Brossier, C., Gennero, M.C., Bonnefond, P., Barlier, F., Exertier, P., 1998. Mean sea level investigations at global and regional scales from Topex / Poseidon. Aviso Newsletter 6, 1-4.

Clark, G.C., Davies, R.G., Hamzepour, B., Jones, C.R., 1975. Explanatory text of the Bandar Anzali quadrangle map 1/250.000. Geological Survey of Iran, D3, 198 pp, Tehran.

Davies, R.G., Jones, C.R., Hamzepour, B., Clark, G.C., 1972. Geology of the Masuleh Sheet, 1/100 000, Northwestern Iran. A Report of Geol. Survey of Iran, no 24, 110 pp, Tehran.

Degens, E.T., Paluska, A., 1979. Tectonic and climatic pulses recorded in the Quaternary sediments of the Caspian-Black Sea regions. Sedimentary Geol., 23, 149-163.

De Mora, S. and Sheikholeslami, M. R., 2002. Final report: interpretation of Caspian Sea sediment data. Contaminant Screening Programme of Caspian Environment Programme, UNCED, Baku, 27 pp

DOEI (Department of Environment of Islamic Republic of Iran), 1998. Caspian Sea environment. National Report of I.R. Iran, Caspian Environment Programme, Baku, 58pp.

Emberger, L. and Sabeti, H., 1962. Forêts denses intertropicales et forêts caspiennes humides. Naturalia Monspeliensia, Botanique, 14: 55 - 61.

Escudié, A.S., Blanc G., Chalié F., Clauer N., Filly A. Gibert E. Massault M., Mélières F. Van Exter S., Zuppi G.M., Gasse F., 1998. Understanding present and past Caspian Sea evolution. Contribution from isotope tracers. In Study of past and current environmental changes in the hydrosphere and the atmosphere ". IAEA, Vienna ; STI/PUB/1024, $623-631$.

Faridi, Z., 1964. Ostracodes in the Plio-Pleistocene sediments of Gorgan and Mazenderan (northern Iran). Bulletin of the Iran Petroleum Institute 14: 532-535.

Giralt, S., Julià, R., Leroy, S., Gasse, F., 2003. Cyclic water level oscillations of the Karabogaz Gol - Caspian Sea system. Earth and Planetary Science Letters 6681, 1-15.

Goy, J.L., Zazo, C., Dabrio, C., 2003. A beach-ridge progradation complex reflecting periodical sea-level and climate variability during the Holocene (Gulf of Almeria, Western Mediterranean). Geomorphology 50, 251-268.

Gulbabazadeh, T., 1997. Sedimentological investigations of Lake Anzali and surrounding Quaternary deposits. PhD Thesis, Ankara University, Turkey, 121 pp (in Turkish). 
Jackson, J., Priestley, K., Allen, M., Berberian, M., 2002. Active tectonic of the South Caspian Basin. Geophys. J. Int., 148, 214-245.

Jones, C.R., 1971. A report on the geology of Bandar-e-Pahlavi Quadrangle, northwestern Iran. Geol. Survey of Iran, no 74, 115 pp., Tehran.

Kazanci N., Leroy S., Ileri Ö., Emre O., Kibar, M. and Öncel, S., submitted. Late Holocene erosion in NW Anatolia from sediments of Lake Manyas, Lake Ulubat and the southern shelf of the Marmara Sea, Turkey. Catena (submitted Nov. 02).

Keudler, P.C., 1978. Final report on the limnological investigation in the Anzali Taleb. Department of Environment, Tehran, 45 p.

Kimball, J.A., 1974. Limnological study of the Anzali Mordab and effluent river system during the years 1971-1973. Technical Report, Thehran. (one h only)

Knight, J., Orford, J.D., Wilson, P., Braley, S.M., 2002. Assessment of temporal changes in coastal sand dune environments using the log-hyperbolic grain-size method. Sedimentology 49, 1229-1252.

Kobori, I., 1973. Historical Background (chapter 3). In: The Paleolithic site at Doura cave in Syria (Eds. H. Suzui \& F. Takai). University of Tokyo, Japan, pp. 60-76. http://www.um.u-tokyo.ac.jp/publish_db/Bulletin/no05/no05003.html.

Kousari, S., 1992. Development of the Sefid Rud deltas, northern Iran. Abstracts, $29^{\text {th }}$ International geological Congress, Kyoto, Japan, pp.317.

Kousari 1997

Kroonenberg, S.B., Storms, J.A., Ignatov, E.I., Kasimov, N.S., 2000. A full sea level cycle in 65 years; barrier dynamics along Caspian shores. Sedimentary Geol., 134., 257-274.

Leontyev, O.K., Federov, P.V., 1953. On the history of the Caspian Sea in Late Glacial and Postglacial times (in Russian). Izv. Adad. Nauk SSSR, Geogr. Ser., 4, 64-74.

Leroy S. and Roiron P., 1996 - Final Pliocene macro and micro floras of the paleovalley of Bernasso (Escandorgue, France). Review of Palaebot. and Palynol. 94: 295-328.

Leroy, S., Marret, F., Gasse, F., Chalié, F., 2000. Understanding the Caspian Sea erratic fluctuations palynological results from the south basin. Terra Nostra 7, Proceedings of $5^{\text {th }}$ ELDP Workshop, Pallanza, p.45-49.

Mamedov, A.V., 1997. The Late Pleistocene-Holocene history of the Caspian Sea. Quaternary Intern. 41/42, 161-166.

Mansimov, M., Aliyev, A., 1994. Reasons of Caspian Sea level fluctuations and predictions for future. Azerbaijan International A1, 2.3, 48-49.

Marret F., Leroy S., Chalié F. and Gasse F. İin press- New organic-walled dinoflagellate cyst genus, species, morphotypes and assemblages, from South Caspian Sea basin sediments (Last glacial and Holocene). Review of Palaebot. and Palynol. 
McLaughlin, J., Anon, M., 1995. Balancing act in a sensitive sea. Statoil Magazine 17 (3), 7 17.

Mescherskaya, A.V., Aleksandrova, N.A., 1993. Caspian Sea level forecast from meteorological data. Russian Meteorology and Hydrology 3, 52-60.

Miall, A.D. 1984. Principles of Sedimentary Basin Analysis. Springer, Berlin-HeilderbergNewYork.

Nordstorm, K.F., Prusty, N., Carter, B. (Eds), 1991. Coastal Dunes: Form and Process. John Wiley Pub., New York, 410 p.

Nowroozi, A.A., 1971. Seismo-tectonics of the Persian Plateau, eastern Turkey, Caucasus and Hindukush regions. Bull. Seismol. Soc. America 61, 317-341.

Okhravi, R., Amini, A., 2001. Characteristics and provenance of the loess deposits of the Gharatikan watershed in northeast Iran. Global and Planetary Change 28, 11-22.

Olah, J., 1990. Pollution in the Anzali lagoon catchment. Preliminary assessment. FAO, Rome, 1-20.

Payan, L.M., 1942. Investigation of Water Level Changes of Caspian Sea. PhD Thesis, Meshed University, 160 pp, Iran (in Persian).

Ramsar, 1997 - Ramsar advisory missions: report no 37, Islamic Republic of Iran. www.ramsar.org/ram_rpt_37e.htm

Ranjbar, Gh.A., 1998. Heavy metal concentration in surficial sediments from Anzali wetland, Iran. Water Air Soil Pollut., 104, 305-312.

Reading, H., 1996. Sedimentary Environments: Processes, Facies and Stratigraphy. Third Ed., Blackwell Pub., Oxford, 689 pp.

Reineck, H.E. and Singh, I.B., 1980. Depositional Sedimentary Environments. Springer Verlag, Berlin, 520 pp.

Rychagov, G.I., 1997. Holocene oscillations of the Caspian Sea and forecasts based on palaeogeographical reconstructions. Quaternary Int., 41/42, 167-172.

Seddletskii, V.S., Baikov, A.A., 1997. The nature of Caspian Sea level fluctuations. Lithology and Mineral Resources 32, 208-215.

Sengor, A.M.C., Natal'in, B.A., Burtman, V.S., 1993. Evolution of the Altaid tectonic collage and Palaeozoic crustal growth in Eurasia. Nature 264, no 6635: 299-307.

Stöcklin, J. and Eftekhar, J. N., 1969. Explanatory text of the Zanjan quadrangle map 1/250 000. Geological Survey of Iran, Report no D4, 61 pp, Tehran.

Stöcklin, J., 1971.Stratigraphic Lexicon of Iran (part 1); central, north and east Iran. Geological Survey of Iran, Report no 18, 338 pp., Tehran.

Stöcklin, J., 1974,. Northern Iran; Albrouse Mountains. In: Mesozoic-Cenozoic Orogenic Belt. Spec. Pub. Geol. Soc. London 4, 213-234. 
Stöcklin, J., 1977. Structural correlation of the Alpine ranges between Iran and central Asia. Geol. Soc. France, Mémoire N8, 333-353.

Sussli, P.E., 1976. The geology of the lower Hazar valley area, central Albrouse, Iran. A report of Geol. Survey of Iran, no 38, 116 pp, Tehran.

Talebi, Kh., 1998. Diazinon residues in the basins of Anzali Lagoon, Iran. Bull. Environ. Contam. Toxicol. 61, 477-483.

Tolouie, E., West, J.R., Billam, J., 1993. Sedimentation and desiltation in the Sefid-Rud reservoir, Iran. In: J. McManus and R. W. Duck (Eds), Geomorphology and Sedimentology of Lakes and Resevoirs, John Wiley and Sons Ltd, New York, p. 125138.

UNESCO-IGCP481, 2003 Dating Caspian Sea Level Change http://www.unesco.org/science/earthsciences/igcp/approved_2003.htm\#481

Velichko, A.A., 1990. Loess-paleosol formation on the Russian plain. Quaternary International 7-8, 103-114.

Venice System, 1959. Final resolution of the symposium on the classification of brackish water. Arch. Oceonogr. Limnol. 11 (suppl), 243-245.

Wright H., E., Ammann B., Stefanova I., Atanassova J., Margalitadze N., Wick L. and Blyakharchuk T., 2003 - Late-Glacial and Early-Holocene dry climates from the Balkan Peninsula to southern Siberia. In: "Aspects of Palynology and Palaeoecology", S. Tonkov (ed.), PENSOFT publishers, Sofia-Moscow, 127-136.

Zohary, M., 1973. Geobotanical foundations of the Middle East. G. Fisher Verlag, Stuttgart.

Zubakov, V.A., 1993. The Caspian Sea level oscillations in the geological past and its forecast. Russian Meteorology and Hydrology 8, 65-70.

\section{Tables}

Table 1. Fluvial sediment transported into Lake Anzali in 1985

Table 2. Water discharge and suspended sediment load of some Anzali rivers in 1992-94.

Table 3. Seasonal water depth $(\mathrm{cm})$ and salinity (\%) in stations 1-15 of Lake Anzali in year 2000. Note that the salinity of a place is given at the surface and at the bottom of the water column.

Table 4. Some ion concentrations (mg. $\left.\mathrm{l}^{-1}\right)$ in sub-basins of Lake Anzali 


\section{Figure captions}

Fig. 1. Location of the study area

Fig. 2. Orography and main river courses of the Gilan-Mazenderan region of northern Iran. The outlines of lake Anzali correspond to year 1984.

Fig. 3. Simplified lithofacies map of southern Caspian lowland of Quaternary.

Fig. 4. Sample sites and sub-basins of Lake Anzali

Fig. 5. Surface and morphology changes of Lake Anzali based on sea level fluctuations since 1972.

Fig. 6. Internal stratigraphy of terrace III and facies B2 from cores.

Fig. 7. Caspian Sea water level changes in between 1925-2000 (see text for detail).

Fig. 8. Water level changes of Caspian Sea in years 1999 and 2000 measured at Anzali town.

Fig.9. Field photos of the lowland

Fig. 10: Terrestrial and aquatic pollen and spores diagram of five surface samples from lake Anzali, in percentages. Black dot for values below $7 \%$.

Fig. 11: Dinoflagellate and other microfossils diagram in concentration (in numbers per $\mathrm{ml}$ ) for five surface samples from lake Anzali. Black dot for values lower than 2200. 